\title{
The Effects of Water Extracts from Tansy on Pea Leaf Weevil and Black Bean Aphid
}

\author{
Natalia Kwiecień1, Janina Gospodarek ${ }^{1 *}$, Elżbieta Boligłowa' ${ }^{1}$ \\ 1 Department of Microbiology and Biomonitoring, University of Agriculture, al. Mickiewicza 21, 31-120 Krakow, \\ Poland \\ * Corresponding author's e-mail: rrjgospo@cyf-kr.edu.pl
}

\begin{abstract}
The purpose of the research conducted was to define the impact of the various aqueous extract concentrations, prepared from the dried (in concentrations 2\%, 5\% and 10\%) and fresh (in concentrations 10\%, 20\% and 30\%) tansy (Tanacetum vulgare L.) mass, on the feeding of pea leaf weevil (Sitona lineatus L.), and the mortality rate of black bean aphid (Aphis fabae Scop.). The studies showed that in order to limit the feeding of pea leaf weevils considerably, it is necessary to use at least $5 \%$ extract of the dried tansy mass or $20 \%$ extract of the fresh tansy mass. The impeding effect on the feeding of pea leaf weevils was correlated positively with the extract concentration. The insecticide effect of the aqueous extract of tansy on black bean aphid was revealed not earlier than after 12 hours with the use of at least $20 \%$ extract of the fresh tansy mass and 5\% extract of the dried mass (only in relation to aphid larvae). Nevertheless, the extracts of lower concentration also demonstrated the insecticide effectiveness although delayed (36-60 hours after the application). As compared to other studies conducted according to the same methodology, it was demonstrated that the tansy aqueous extracts are characteristic for a high deterrent activity in relation to the pea leaf weevil beetles (higher than the extracts of absinthe and similar to the extracts of pepper mint and sage) and a quite high aphicidal activity (higher effectiveness than in the case of the aqueous extracts of lemon balm but lower than the extracts of tarragon and absinthe).
\end{abstract}

Keywords: water extracts, Tanacetum vulgare L., biological control

\section{INTRODUCTION}

Tansy (Tanacetum vulgare L.) is a perennial from the aster family (Asteraceae) which is widespread in Poland. It is found mostly on agricultural waste grounds, waysides, river banks and on open spaces [Konieczny and Ślęzak 2019]. Tansy flower heads and herbs are used in medicine. The tansy herb contains up to $0.6 \%$ and flowers from $1 \%$ to $1.5 \%$ of oil the main ingredient of which is toxic $\beta$-thujone (approximately 70\%) [Hadaś and Derda 2014].

Plant extracts are an advantageous alternative to chemical preparations, because their impact on the human health and natural environment is lower. The hitherto research has demonstrated that tansy may be used in controlling some crop pests, e.g. aphids [Dancewicz et al. 2011]. In the latest literature there is no data on the possibility of using the tansy extracts for other pest control. The older publications report that the aqueous extracts of tansy have an antifeedant effects on imported cabbageworm larvae (Pieris rapae (L.)), diamondback moth larvae (Plutella xylostella (L.)) [Brewer and Ball 1981, Hough-Goldstein and Hahn 1992], Colorado potato beetle adults and larvae, (Leptinotarsa decemlineata (Say)) [Hough-Goldstein 1990], and codlingmoth larvae (Cydia pomonella (L.)) [Suomi et al. 1986]. In the tests carried out with the larvae (1.-4. instar) and adults of L. decemlineata, the extracts from $T$. vulgare showed a high toxicity rate in 48 hours, and LC50's of $33.3 \%$ [Erturk and Uslu 2007]. The essential oils from this plant were the object of tests as fumigants for the stored product pests [Karaborklu et al. 2011] and against the host-seeking nymphs of the common tick Ixodes ricinus (L.) [Palsson 
et al. 2008]. They were also the most effective repellents in the group of the essential oils of 27 plant species in relation to the neonate larvae of C. pomonella [Landolt et al. 1999]. T. vulgare is also mentioned along laurel (Laurus nobilis L.), mullein (Verbascum thapsus L.), and wormwood (Artemisia vulgare L.) as prospective plants for the isolation of the biological active substances to control whitefly, Trialeurodes vaporariorum [Chermenskaya et al. 2009]. Nevertheless, the available literature lacks any reports on the possibilities of limiting the feeding of beetles from the true weevils family (Curculionidae) or black bean aphid (Aphis fabae Scop.) - which is very dangerous in the Polish climate - with the use of the aqueous extracts of tansy.

Pea leaf weevil (Sitona lineatus L., Curculionidae) is the main pest of young leguminous plants. Larvae feed underground, damaging root nodules and reducing the nitrogen bonding, whereas adult beetles cause characteristic damage along the leaf edges in the "U" letter shape, thus reducing photosynthesis and leading to the decrease in the pod production [Reddy et al. 2018, Vankosky et al. 2011]. Black bean aphid is a polyphagous species, which is common worldwide. Its harmfulness consists not only in sucking out the juices from leaves and shoots but it is also related to the transmission of viral diseases among plants [Shah et al. 2018].

The purpose of the research conducted was to define the impact of the various aqueous extract concentrations, prepared from the dried and fresh tansy mass, on the feeding of pea leaf weevil and the mortality rate of black bean aphid.

\section{MATERIAL AND METHODS}

The experiment was conducted in the laboratory, in six replicates. The extracts from dry matter of $T$. vulgare were prepared at the concentration assumed conventionally as $2 \%, 5 \%$ and $10 \%$ (dried plants + cold redistilled water in proportions of $2: 100,5: 100$ and $10: 100$ ) and at concentration of $10 \%, 20 \%$ and $30 \%$ for fresh matter (fresh above-ground parts of plants + cold redistilled water in proportions of $10: 100,20: 100$ and $30: 100$ ). For the period of 24 hours, the extracts were stored in the dark, then filtered through filter papers and immediately used for the conduct of the experiment. The test was conducted on Petri dishes, and the substrate consisted of a moist filter paper. The plant leaves (Pisum sativum L. in the case of S. lineatus, Philadelphus coronarius L. in the case of $A$. fabae) were soaked for 3 seconds in adequate plant extracts and in distilled water used as control, and then dried at room temperature. One leaf of a plant suitable for a specific object was placed in each dish and then pests were introduced - one adult of $S$. lineatus (male and female separately), fifteen wingless females of $A$. fabae and fifteen aphid larvae.

The assessment of the beetle feeding intensity was carried out by measuring the surface of feeds caused by $S$. lineatus at 8 hour intervals. The values of palatability index as the ratio of the percentage area of leaves consumed in individual objects to the percentage area of leaves consumed in the control was calculated. Furthermore, the absolute deterrence index which takes into account the relationship between the area of leaves consumed in the individual objects and the area of leaves consumed in the control was established:

$$
\mathrm{Bwd}=[(\mathrm{K}-\mathrm{T}):(\mathrm{K}+\mathrm{T})] \cdot 100
$$

where: $B w d-$ absolute deterrence index.

$K-$ area of leaves consumed in control $\left[\mathrm{mm}^{2}\right]$.

$T$ - area of leaves consumed in individual objects $\left[\mathrm{mm}^{2}\right]$.

In order to examine the effect of $T$. vulgare extracts on A. fabae, the mortality of wingless female and aphid larvae was determined at 12 hour intervals.

The obtained results were then subjected to analysis by means of STATISTICA 13.1 software package. The significance of differences between the means was tested by univariate analysis of variance, and the means were differentiated by Fisher's LSD test at $\alpha=0.05$.

\section{RESULTS}

The extracts prepared from the dried tansy mass in higher concentrations (5\% and 10\%), on all the dates of the observations carried out, considerably limited the feeding of pea leaf weevil (Table 1). However, the extract of $2 \%$ concentration turned out to be ineffective. A similar dependence was demonstrated in the case of the extract of the fresh tansy mass - the extracts of higher concentrations, on all the dates, considerably limited the feeding of pea leaf weevil males. In turn, the weakest $(10 \%)$ extract of the fresh mass 
demonstrated delayed effectiveness, i.e. after 24 hours from the application.

The females of pea leaf weevils ate more leaf blade than the males of this pest. As far as the dried tansy extract is concerned, the highest concentration $(10 \%)$ extract was the most effective. Significantly weaker feeding of females was confirmed from the $16^{\text {th }}$ hour of the experiment and it continued until the end of the tests. The dried mass extract of $5 \%$ concentration was slightly weaker because the significant reduction on the feeding among females was observed only between the $16^{\text {th }}$ and $48^{\text {th }}$ hour of the experiment. Yet, $2 \%$ extract of the dried mass did not significantly affect the feeding of this stage pest. On the other hand, the extracts prepared based on the fresh tansy fragments impeded the feeding of females throughout the tests at a similar level, except the extract of the lowest concentration, the effect of which ceased after 48 hours from its application.

The absolute deterrence index for the males of pea leaf weevils, in all the objects, was positive and it implies that the extracts applied were characteristic for the impeding effect on the feeding of the pests subject to the analysis (Figure 1). As far as the females in the object with $2 \%$ dried mass extract are concerned, the negative value of this index was discovered - this acknowledged the stimulating effect of the extract. The strongest deterrent effect on the males was observed in the extracts prepared from the dried mass in the concentration of $5 \%$ and $10 \%$, and the extract of the fresh tansy mass in the concentration of $30 \%$. In turn, the females were affected the most by the fresh mass extracts in the concentration of $20 \%$ and $30 \%$. As far as the females are concerned, the increase in the concentration of the extract used was accompanied by the increase in the value of the absolute deterrence index. An analogous tendency was discovered among males, but only in the case of the extracts of the fresh tansy mass.

The palatability index for males was the highest in the event of applying the weakest extract of the dried mass in the concentration of $2 \%$; and when using the weakest concentration fresh mass extract (10\%). Analogously, in the event of females, the palatability index was the highest in the object of applying the weakest extract of the dried mass in the concentration of $2 \%$ (Figure 2). In general, the slightly higher values of the palatability index were recorded among the females.

As far as the black bean aphid is concerned, the extracts of the fresh tansy mass were more effective. The extracts in the concentration of $20 \%$ and $30 \%$ caused the significant growth in the mortality rate among the apterous females of this pest as early as after 24 hours from the commencement of the experiment. Slightly later (after 36 hours), such an effect was recorded also with the use of $10 \%$ extract. In the objects with the extracts prepared from the dried tansy mass, the significant growth in the mortality rate was observed after 60 hours from the commencement

Table 1. The effect of extracts from Tanacetum vulgare L. on the surface of feeds caused by the females and males of Sitona lineatus L. $\left[\mathrm{mm}^{2}\right]$. C - control, DM - dry matter, FM - fresh matter.

\begin{tabular}{|c|c|c|c|c|c|c|c|c|c|c|}
\hline Object & $8 \mathrm{~h}$ & $16 \mathrm{~h}$ & $24 \mathrm{~h}$ & $32 \mathrm{~h}$ & $40 \mathrm{~h}$ & $48 \mathrm{~h}$ & $56 \mathrm{~h}$ & $72 \mathrm{~h}$ & $120 \mathrm{~h}$ \\
\hline \multicolumn{7}{|c|}{ Males } \\
\hline C & $9.9 \mathrm{bc}$ & $35.3 \mathrm{c}$ & $65.7 \mathrm{c}$ & $87.9 \mathrm{~b}$ & $109.6 \mathrm{~b}$ & $128.9 \mathrm{c}$ & $149.0 \mathrm{~b}$ & $161.6 \mathrm{~b}$ & $196.3 \mathrm{c}$ \\
\hline DM 2\% & $8.1 \mathrm{bc}$ & $25.9 \mathrm{bc}$ & $51.5 \mathrm{bc}$ & $60.2 \mathrm{ab}$ & $72.5 \mathrm{ab}$ & $94.4 \mathrm{bc}$ & $103.3 \mathrm{ab}$ & $120.3 \mathrm{ab}$ & $138.3 \mathrm{bc}$ \\
\hline DM 5\% & $0.0 \mathrm{a}$ & $1.6 \mathrm{a}$ & $12.8 \mathrm{a}$ & $26.7 \mathrm{a}$ & $49.4 \mathrm{a}$ & $65.1 \mathrm{ab}$ & $85.0 \mathrm{a}$ & $92.6 \mathrm{a}$ & $97.2 \mathrm{ab}$ \\
\hline DM 10\% & $1.3 \mathrm{ab}$ & $6.5 \mathrm{ab}$ & $18.6 \mathrm{a}$ & $29.6 \mathrm{a}$ & $38.7 \mathrm{a}$ & $45.0 \mathrm{a}$ & $63.6 \mathrm{a}$ & $64.6 \mathrm{a}$ & $66.4 \mathrm{a}$ \\
\hline FM 10\% & $4.4 \mathrm{abc}$ & $18.6 \mathrm{abc}$ & $33.2 \mathrm{ab}$ & $35.3 \mathrm{a}$ & $59.1 \mathrm{a}$ & $68.5 \mathrm{ab}$ & $76.9 \mathrm{a}$ & $93.3 \mathrm{a}$ & $106.7 \mathrm{ab}$ \\
\hline FM 20\% & $1.0 \mathrm{ab}$ & $9.7 \mathrm{ab}$ & $20.7 \mathrm{a}$ & $30.6 \mathrm{a}$ & $50.7 \mathrm{a}$ & $63.8 \mathrm{ab}$ & $76.4 \mathrm{a}$ & $86.3 \mathrm{a}$ & $94.4 \mathrm{ab}$ \\
\hline FM 30\% & $0.0 \mathrm{a}$ & $14.4 \mathrm{abc}$ & $19.9 \mathrm{a}$ & $27.5 \mathrm{a}$ & $37.7 \mathrm{a}$ & $48.9 \mathrm{ab}$ & $57.5 \mathrm{a}$ & $63.5 \mathrm{a}$ & $70.0 \mathrm{ab}$ \\
\hline \multicolumn{7}{|c|}{ Females } & & & \\
\hline C & $13.6 \mathrm{a}$ & $53.4 \mathrm{~b}$ & $88.7 \mathrm{~b}$ & $109.3 \mathrm{~b}$ & $119.0 \mathrm{~b}$ & $159.5 \mathrm{~b}$ & $179.7 \mathrm{~b}$ & $213.9 \mathrm{~b}$ & $235.1 \mathrm{~b}$ \\
\hline DM 2\% & $14.9 \mathrm{a}$ & $54.9 \mathrm{~b}$ & $92.1 \mathrm{~b}$ & $115.9 \mathrm{~b}$ & $134.1 \mathrm{~b}$ & $162.3 \mathrm{~b}$ & $184.4 \mathrm{~b}$ & $215.3 \mathrm{~b}$ & $248.2 \mathrm{~b}$ \\
\hline DM 5\% & $7.3 \mathrm{a}$ & $19.4 \mathrm{a}$ & $40.0 \mathrm{a}$ & $53.1 \mathrm{a}$ & $57.0 \mathrm{a}$ & $90.0 \mathrm{a}$ & $132.4 \mathrm{ab}$ & $144.9 \mathrm{ab}$ & $167.8 \mathrm{ab}$ \\
\hline DM 10\% & $3.4 \mathrm{a}$ & $18.6 \mathrm{a}$ & $31.4 \mathrm{a}$ & $42.1 \mathrm{a}$ & $64.6 \mathrm{a}$ & $76.1 \mathrm{a}$ & $78.5 \mathrm{a}$ & $85.3 \mathrm{a}$ & $86.3 \mathrm{a}$ \\
\hline FM 10\% & $1.0 \mathrm{a}$ & $11.5 \mathrm{a}$ & $31.4 \mathrm{a}$ & $41.3 \mathrm{a}$ & $65.9 \mathrm{a}$ & $83.5 \mathrm{a}$ & $113.6 \mathrm{ab}$ & $121.2 \mathrm{a}$ & $176.4 \mathrm{ab}$ \\
\hline FM 20\% & $0.0 \mathrm{a}$ & $13.6 \mathrm{a}$ & $25.6 \mathrm{a}$ & $39.0 \mathrm{a}$ & $50.2 \mathrm{a}$ & $67.7 \mathrm{a}$ & $76.6 \mathrm{a}$ & $90.5 \mathrm{a}$ & $92.8 \mathrm{a}$ \\
\hline FM 30\% & $13.6 \mathrm{a}$ & $23.3 \mathrm{a}$ & $31.9 \mathrm{a}$ & $38.5 \mathrm{a}$ & $54.4 \mathrm{a}$ & $65.1 \mathrm{a}$ & $71.1 \mathrm{a}$ & $77.7 \mathrm{a}$ & $88.9 \mathrm{a}$ \\
\hline
\end{tabular}

* Values for individual terms of observations marked by different letters are statistically different $(\alpha=0.05)$. 


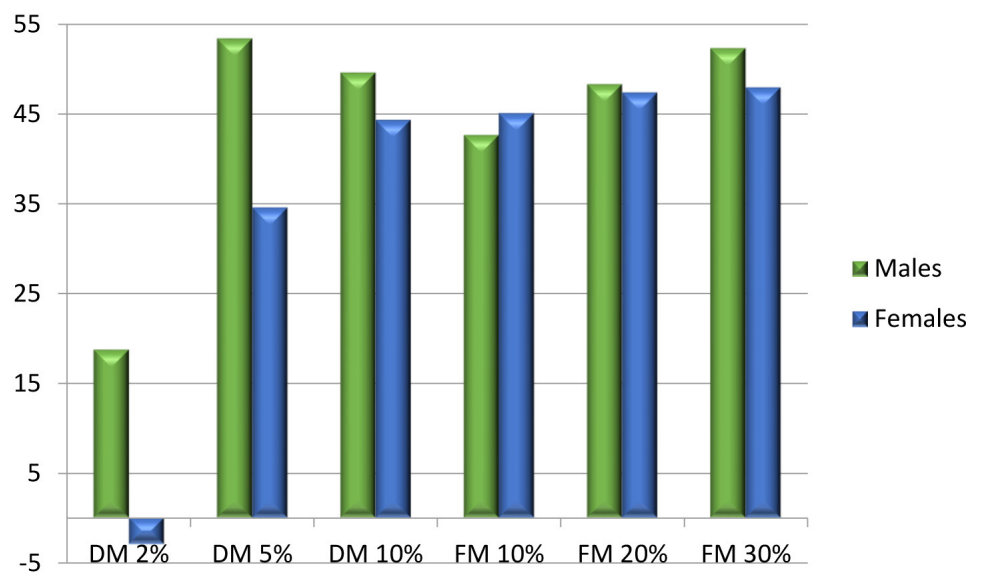

Fig. 1. Absolute deterrence index. Symbols as in Table 1.

of the experiment; their effectiveness was similar regardless of the concentration used.

Similar regularities were observed in the event of the larvae of black bean aphid. The extracts in the concentration of $5 \%$ and $10 \%$ of the dried mass, and $20 \%$ and $30 \%$ of the fresh mass significantly increased the mortality rate among the larvae as early as during the first observation, i.e. in the $12^{\text {th }}$ hour from the commencement of the experiment. After 36 hours of the tests, all the extracts significantly increased the mortality rate among the larvae of $A$. fabae. As with the females, the extracts prepared from the fresh tansy mass were more effective with larvae.

\section{DISCUSSION}

However, hardly any research has been done so far on the impact of the aqueous extracts of tansy on the feeding activity of plant pests. Comparing the antifeedant effect of the aqueous extract of tansy, sage, basil, catnip, dill, and rue on the adult and larvae of $L$. decemlineata, Hough-Godstein [1990] demonstrated the strongest effect in the case of tansy. Adult beetles refused to feed on leaf disks dipped in a $10 \%(2 \mathrm{~g}$ in $20 \mathrm{ml})$ suspension of tansy tissue, even after $22 \mathrm{~h}$. The tansy treatments caused substantial mortality to the beetle larvae that fed on them from egg hatching. Dancewicz and Gabrys [2008] tested the combination of the garlic extract and the extract of tansy and absinthe wormwood (Artemisia absinthium L.) with the solution of garden green soap, as well as a commercial preparation on green peach aphid (Myzus persicae Sulz.). Nevertheless, the strongest repellent effect was determined in the commercial garlic preparation together with the garden green soap. However, the available literature lacks any data on the possibility of limiting the feeding of pests from the true weevil family, including pea leaf weevils, with the use of tansy aqueous extracts. The research on the impact of the aqueous extracts of other herbs on the feeding of pea leaf

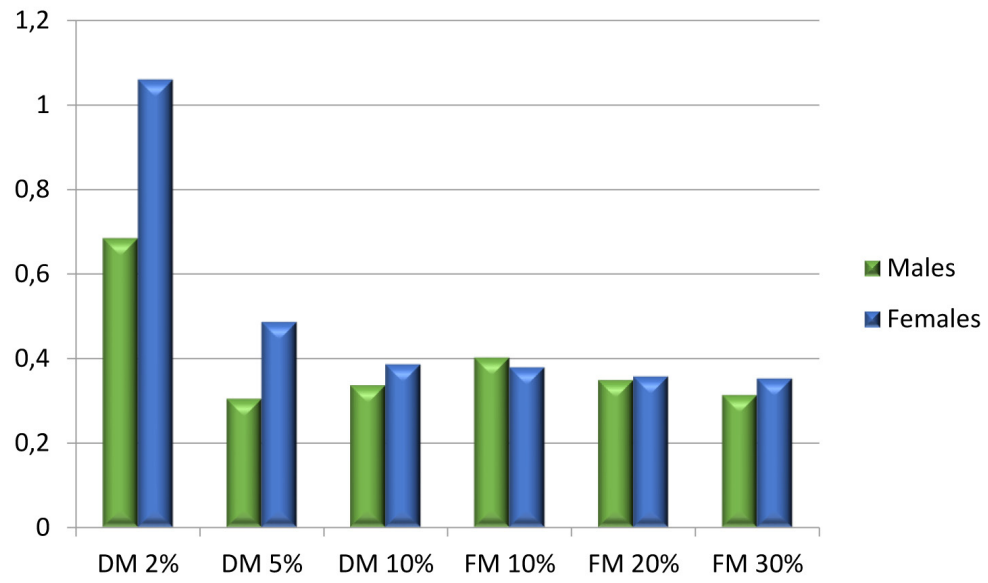

Fig. 2. Palatability index. Symbols as in Table 1. 
Table 2. The effect of extracts from Tanacetum vulgare L. on mortality of apterous females and larvae of Aphis fabae Scop. [\%]. Symbols as in Table 1.

\begin{tabular}{|c|c|c|c|c|c|c|c|c|c|c|}
\hline Object & $12 \mathrm{~h}$ & $24 \mathrm{~h}$ & $36 \mathrm{~h}$ & $48 \mathrm{~h}$ & $60 \mathrm{~h}$ & $72 \mathrm{~h}$ & $84 \mathrm{~h}$ & $96 \mathrm{~h}$ & $108 \mathrm{~h}$ & $120 \mathrm{~h}$ \\
\hline \multicolumn{11}{|c|}{ Apterous females } \\
\hline C & $1.1 \mathrm{a}^{*}$ & $2.2 \mathrm{a}$ & $7.8 \mathrm{a}$ & $13.3 \mathrm{a}$ & $16.7 \mathrm{a}$ & $17.8 \mathrm{a}$ & $28.9 a$ & $41.1 \mathrm{a}$ & $52.2 \mathrm{a}$ & $65.6 \mathrm{a}$ \\
\hline DM $2 \%$ & $4.4 \mathrm{a}$ & $5.6 a b$ & $23.3 \mathrm{abc}$ & $37.8 \mathrm{bc}$ & $52.2 \mathrm{bc}$ & $73.3 \mathrm{bcd}$ & $88.9 \mathrm{~cd}$ & $95.6 \mathrm{bc}$ & $95.6 \mathrm{~b}$ & $95.6 \mathrm{~b}$ \\
\hline DM 5\% & $2.2 \mathrm{a}$ & $2.2 \mathrm{a}$ & $17.8 \mathrm{abc}$ & $30.0 \mathrm{abc}$ & $44.4 \mathrm{~b}$ & $55.6 \mathrm{~b}$ & $67.8 \mathrm{~b}$ & $84.4 \mathrm{~b}$ & $87.8 \mathrm{~b}$ & $91.1 \mathrm{~b}$ \\
\hline DM $10 \%$ & $2.2 \mathrm{a}$ & $2.2 \mathrm{a}$ & $10.0 \mathrm{ab}$ & $21.1 \mathrm{ab}$ & $41.1 \mathrm{~b}$ & $63.3 \mathrm{bc}$ & $75.6 \mathrm{bc}$ & $87.8 \mathrm{bc}$ & $93.3 \mathrm{~b}$ & $93.3 \mathrm{~b}$ \\
\hline FM $10 \%$ & $3.3 \mathrm{a}$ & $3.3 \mathrm{a}$ & $25.6 \mathrm{c}$ & $42.2 \mathrm{c}$ & $72.2 \mathrm{c}$ & $86.7 \mathrm{~d}$ & $95.5 \mathrm{~d}$ & $100.0 \mathrm{c}$ & $100.0 \mathrm{~b}$ & $100.0 \mathrm{~b}$ \\
\hline FM $20 \%$ & $3.3 \mathrm{a}$ & $12.2 \mathrm{bc}$ & $28.9 \mathrm{c}$ & $35.6 \mathrm{bc}$ & $51.1 \mathrm{bc}$ & $67.8 \mathrm{bcd}$ & $76.7 \mathrm{bc}$ & $91.1 \mathrm{bc}$ & $95.6 \mathrm{~b}$ & $98.9 \mathrm{~b}$ \\
\hline FM 30\% & $3.3 \mathrm{a}$ & $15.6 \mathrm{c}$ & $31.1 \mathrm{c}$ & $47.8 \mathrm{c}$ & $64.4 \mathrm{c}$ & $75.6 \mathrm{~cd}$ & $80.0 \mathrm{bc}$ & $93.3 \mathrm{bc}$ & $97.8 \mathrm{~b}$ & $98.9 \mathrm{~b}$ \\
\hline \multicolumn{11}{|c|}{ Larvae } \\
\hline C & $2.2 \mathrm{a}^{*}$ & $2.2 \mathrm{a}$ & $8.9 \mathrm{a}$ & $15.6 \mathrm{a}$ & $17.8 \mathrm{a}$ & $18.9 a$ & $26.7 \mathrm{a}$ & $33.3 \mathrm{a}$ & $38.9 a$ & $42.2 \mathrm{a}$ \\
\hline DM 2\% & $11.1 \mathrm{ab}$ & $18.9 \mathrm{bc}$ & $30.0 \mathrm{~b}$ & $38.9 \mathrm{bc}$ & $57.8 \mathrm{bc}$ & $75.6 \mathrm{~cd}$ & $86.7 \mathrm{~b}$ & $93.3 \mathrm{~b}$ & $93.3 \mathrm{~b}$ & $93.3 \mathrm{~b}$ \\
\hline DM 5\% & $18.9 \mathrm{~b}$ & $22.2 \mathrm{bc}$ & $31.1 \mathrm{~b}$ & $38.9 \mathrm{bc}$ & $60.0 \mathrm{bc}$ & $70.0 \mathrm{bc}$ & $76.7 \mathrm{~b}$ & $84.4 \mathrm{~b}$ & $91.1 \mathrm{~b}$ & $91.1 \mathrm{~b}$ \\
\hline DM $10 \%$ & $18.9 \mathrm{~b}$ & $24.4 \mathrm{bc}$ & $33.3 \mathrm{~b}$ & $37.8 \mathrm{~b}$ & $48.9 \mathrm{~b}$ & $58.9 \mathrm{~b}$ & $76.7 \mathrm{~b}$ & $78.9 \mathrm{~b}$ & $88.9 \mathrm{~b}$ & $88.9 \mathrm{~b}$ \\
\hline FM $10 \%$ & $11.1 \mathrm{ab}$ & $11.1 \mathrm{ab}$ & $36.7 \mathrm{bc}$ & $53.3 \mathrm{~cd}$ & $61.1 \mathrm{bc}$ & $68.9 \mathrm{bc}$ & $83.3 \mathrm{~b}$ & $83.3 \mathrm{~b}$ & $93.3 \mathrm{~b}$ & $96.7 \mathrm{~b}$ \\
\hline FM 20\% & $20.0 \mathrm{~b}$ & $32.2 \mathrm{c}$ & $56.7 \mathrm{~d}$ & $62.2 \mathrm{~d}$ & $72.2 \mathrm{c}$ & $86.7 \mathrm{~d}$ & $91.1 \mathrm{~b}$ & $91.1 \mathrm{~b}$ & $100.0 \mathrm{~b}$ & $100.0 \mathrm{~b}$ \\
\hline FM 30\% & $18.9 \mathrm{~b}$ & $22.2 \mathrm{bc}$ & $46.7 \mathrm{~cd}$ & $62.2 \mathrm{~d}$ & $68.9 \mathrm{c}$ & $75.6 \mathrm{~cd}$ & $82.8 \mathrm{~b}$ & $91.1 \mathrm{~b}$ & $96.7 \mathrm{~b}$ & $97.8 \mathrm{~b}$ \\
\hline
\end{tabular}

* Values for individual terms of observations marked by different letters are statistically different $(\alpha=0.05)$.

weevil demonstrates that generally, the aqueous extracts based on the dried mass are characterized by higher effectiveness [Biniaś et al. 2017, Rusin et al. 2016 b]. As far as pepper mint (Mentha piperita L.) is concerned, the dried and fresh mass aqueous extracts significantly limited the feeding of the females of pea leaf weevils; yet, there was no significant limitation confirmed in the feeding of males [Biniaś et al. 2017]. In the event of the females of pea leaf weevils, in the $36^{\text {th }}$ hour of the experiment, a $10 \%$ extract of the dried pepper mint impeded feeding by $91 \%$; while the tansy tested by us - under the same experiment conditions - caused the limitation of the feeding of females by approximately $61 \%$. In turn, as regards the fresh mass extracts, $10 \%$ pepper mint extract limited the feeding of the females of pea leaf weevil in the $36^{\text {th }}$ hour by $45 \%$ and the tansy extract analysed by us limited it by $65 \%$. Rusin et al. [2016 b] demonstrated that $10 \%$ extract of the dried mass of absinthe limited the feeding of both the females and males of pea leaf weevil the most. The feeding of the males of pea leaf weevil was limited in the $32^{\text {nd }}$ hour of the experiment by $39 \%$, and as far as females are concerned - by $25 \%$. Compared to this plant, the tansy extract demonstrates a stronger activity at the similar moment of the experiment. Biniaś et al. [2016], when testing sage (Salvia officinalis L.) aqueous extracts, similarly as during our experiments with tansy, recorded the highest impediment of the feeding of the females of pea leaf weevils with the use of $30 \%$ extract of the fresh mass of this plant. A similar effect was demonstrated by $10 \%$ extract of the dried sage, but only up to the $60^{\text {th }}$ hour of the experiment. As far as the pea leaf weevil males are concerned, the highest concentration extracts, i.e. $10 \%$ dried extract and $30 \%$ fresh extracts of sage, turned out to be the most effective and the activity limiting feeding was observed until the end of the experiment. As compared to the above-mentioned tests, $10 \%$ extract of dried sage affected the females of pea leaf weevil similarly to the analogous extract of the tested tansy. Yet, the tansy extract was more effective among the pea leaf weevil males.

The pepper mint extracts were characteristic for a noticeable activity impeding the feeding of the pea leaf weevil females, which is confirmed in the high values of the absolute deterrence index. The highest value (70) was recorded for $5 \%$ dried pepper mint extract, and as regards the fresh mass extracts, the highest value (48) was recorded with $30 \%$ extract. In our research, the highest value (44) among the dried tansy extracts was recorded in $10 \%$ extracts. In turn, the highest index value in the fresh tansy mass extracts was at the level of 48 for $30 \%$ extract. As regards the males, the deterrence index for 5\% dried pepper mint extract was negative, which is a stimulating and undesired effect [Biniaś et al. 2017]. Similar tendencies were observed in our research but in relation to females. In the object 
with $2 \%$ dried tansy extract, the negative value of the absolute deterrence index was determined. However, in relation to the males, all the values were positive.

While comparing the tansy extract and the absinthe extract [Rusin et al. 2016 b] it may be stated that the absinthe extracts were characterized by a weaker impeding effect on the feeding of pea leaf weevils. The absolute deterrence index was 16 for females and 8 for males in the case of $10 \%$ dried absinthe extract. While, Rusin and Gospodarek [2018] demonstrated that the extracts of lemon balm (Melissa officinalis L.) had the high values of the absolute deterrence index among the pea leaf weevil females. The highest value for the females was 68 with $10 \%$ dried lemon balm extract and 18 among the pea leaf weevil males.

There is little information on the impact of the tansy extract on the feeding of aphids. In the research carried out by Dancewicz et al. [2011] it was demonstrated that the extract of garlic and tansy had a deterrent effect at the stage of feeding by aphids. The electronic registration (EPG) of the behaviour of the green peach aphid on the leaves treated with plant extracts and garden green soap confirmed that in the locations with the extract of garlic and green soap, as well as garlic and tansy, the lowest percentage of probes was observed which contained a bast phase $(6 \%$ and $7 \%$, accordingly) as compared to control probes. At the same time, the duration of the first bast salivation period was longer, and a salivation percentage as regards the activity of aphids was the highest among aphids on the leaves treated with garlic with soap and garlic with tansy. Rusin and Gospodarek [2018], when analysing the dried lemon balm extracts, confirmed the significant mortality rate among the females and larvae of black bean aphid with the use of the highest concentration extracts. After 120 hours of the experiment, $10 \%$ dried lemon balm extract caused the mortality rate of the aphid females at the level of $100 \%$, and the larvae at the level of $83.3 \%$. In turn, $30 \%$ extract of the fresh mass of lemon balm caused the larvae mortality rate of: females $-25 \%$, larvae $-56.7 \%$, respectively. As far as our research is concerned, 100\% mortality rate of $A$. fabae Scop. females was recorded in the $96^{\text {th }}$ hour of the experiment in the object with $10 \%$ extract of the fresh tansy mass. In turn, $100 \%$ larvae mortality rate was observed in the object with the use of $20 \%$ extract of the fresh mass in the $108^{\text {th }}$ hour of the experiment.
Abdulhay and Yonius [2019] evaluated the insecticide effect of the alcohol extracts of ginger rhizome (Zingiber officinale Roscoe) on black bean aphid. The results confirmed the high insecticide effect of $Z$. officinale extract, and the outcome changed depending on the concentrations used. The concentration of $20 \mathrm{mg} / \mathrm{ml}$ induced the highest mortality rate $(70 \%)$ among the females after 48 hours. For comparison, in the $48^{\text {th }}$ hour of our experiment, these values were much lower $-21.1 \%$ for the females and $37.8 \%$ for the larvae in the case of the highest concentration dried mass extract; as far as 30\% extract of fresh mass is concerned this is $47.8 \%$ for the females and $62.2 \%$ for the larvae of aphids. However, it should be taken into account that the abovementioned extract was based on alcohol and this type of extracts is generally more effective.

The pepper mint extracts affected the mortality rate of $A$. fabae larvae to a greater degree than apterous females [Biniaś et al. 2017]. The experiment conducted by us demonstrated that all the tansy extracts had a similar effect on the larvae and $A$. fabae apterous females. The extracts of the fresh and dried mass of tarragon contributed to the increase in the mortality rate among apterous females and the larvae of pea aphids (Acyrthosiphon pisum Harris). The 100\% mortality rate among aphid females was recorded in the $72^{\text {nd }}$ hour of the experiment in the objects with the strongest (10\%) extract of the dried mass. In turn, the strongest (30\%) extract of the fresh mass caused $100 \%$ mortality rate among the females in the $96^{\text {th }}$ hour of the experiment. As far as the aphid larvae are concerned, in the $84^{\text {th }}$ hour of tests, $100 \%$ mortality rate was determined in the objects with the use of the strongest extracts of the dried and fresh mass of tarragon [Rusin et al. 2016 a]. As regards absinthe, 100\% mortality rate among apterous females was recorded in the $84^{\text {th }}$ hour of the experiment in the objects with $5 \%$ and $10 \%$ extracts of the dried mass. In the $96^{\text {th }}$ hour of the tests, the use of all the extracts of the fresh mass resulted in $100 \%$ mortality rate among aphid females [Rusin et al. 2016 b]. Iqbal et al. [2011] also studied the impact of six different aqueous extracts: orange peel (Citrus sinen$\mathrm{sis}$ ), spiny gourd (Momordica dioica), garlic ( $\mathrm{Al}$ lium vineale), pot marigold (Marigold), pepper (Capsicum frutescens) and tobacco (Nicotiana tabacum) on aphids. The aqueous extracts had various effects on the aphid population. The application of the orange peel extract resulted in 
the maximal mortality rate among aphids (66\%), followed by the garlic extract (58\%), tobacco extract (58\%), spiny gourd extract (Momordica dioica) (58\%), red pepper extract (57\%), and pot marigold extract (Marigold) (50\%), after 144 hours of the experiment. When comparing our results with the findings provided above, it may be stated that the tansy aqueous extract is characterized by the considerably high aphicidal ability. The use of the dried tansy extracts resulted in the mortality rate of $90 \%$ among aphids, while the fresh mass extracts were at the level close to $100 \%$ after 120 hours from the commencement of the experiment.

\section{CONCLUSIONS}

1. In order to limit the feeding of pea leaf weevils considerably, it is necessary to use at least 5\% extract of the dried tansy mass or $20 \%$ extract of the fresh tansy mass.

2. The impeding effect on the feeding of pea leaf weevils was correlated positively with the extract concentration.

3. The insecticide effect of the aqueous extract of tansy on black bean aphid was revealed not earlier than after 12 hours with the use of at least $20 \%$ extract of the fresh tansy mass and $5 \%$ extract of the dried mass (only in relation to aphid larvae). Nevertheless, the extracts of lower concentration also demonstrated the insecticide effectiveness, although delayed (3660 hours after the application).

4. As compared to other studies conducted according to the same methodology, it was demonstrated that tansy aqueous extracts are characteristic for a high deterrent activity in relation to pea leaf weevil beetles (higher than the extracts of absinthe and similar to the extracts of pepper mint and sage) and a quite high aphicidal activity (higher effectiveness than in the case of the aqueous extracts of lemon balm but lower than the extracts of tarragon and absinthe).

\section{Acknowledgments}

Scientific publication financed by the Ministry of Science and Higher Education of the Republic of Poland

\section{REFERENCES}

1. Abdulhay H.S., Yonius M.I. 2019. Zingiber officinale an alternative botanical insecticide against black bean aphid (Aphis fabae Scop). Baghdad Sci. J., 16(2), 2315-2321.

2. Biniaś B., Gospodarek J., Rusin M. 2016. Effect of sage water extracts on reduction of feeding of pea leaf weevil. J. Ecol. Eng., 17(2), 157-162.

3. Biniaś B., Gospodarek J., Rusin M. 2017. Effect of water extract from mint on selected crop pests feeding and survival. J. Ecol. Eng., 18(2), 119-128.

4. Brewer G. J., Ball H. J. 1981. A feeding deterrent effect of a water extract of tansy (Tanacetum vulgare L., Compositae) in three lepidopterous larvae. J. Kans. Entomol. Soc., 54, 733-736.

5. Chermenskaya T.D., Petrova M.O., Savelieva E.I. 2009. Laboratory and field evaluation of biological active substances of plant origin against greenhouse whitefly, Trialeurodes vaporariorum Westw. (Homoptera: Aleyrodidae). Arch. Phytopathology Plant Protect., 42, 864-873.

6. Dancewicz K., Gabryś B. 2008. Effect of Allium sativum, Artemisia absinthium and Tanaceum vulgare extracts on the behavior of the green peach aphid Myzus persicae (Sulz.) during plant colonization. Pestycydy/Pesticides, 3-4, 93-99 (in Polish).

7. Dancewicz K., Gabryś B., Przybylska M. 2011. Effect of garlic (Allium sativum L.) and tansy (Tanacteum vulgare L.) extracts and potassic horticultural soap on the probing and feeding behaviour of Myzus persicae (Sulzer, 1776). Aphids and other Hemipterous Insects, 17, 129-136.

8. Erturk O., Uslu U. 2007. Antifeedant, growth and toxic effects of some plant extracts on Leptinotarsa decemfineata (Say.) (Coleoptera, Chrysomelidae). Fresen. Environ. Bull., 16, 601-607.

9. Hadaś E., Derda M. 2014. Medicinal plants in diseases caused by parasitic protozoa. Hygeia Public Health, 49(3), 442-448 (in Polish).

10. Hough-Goldstein J. A. 1990. Antifeedant effects of common herbs on the Colorado potato beetle (Coleoptera: Chrysomelidae). Environ. Entomol., 19, 234-238

11. Hough-Goldstein J., Hahn S. P. 1992. Antifeedant and oviposition deterrent activity of an aqueous extract of Tanacetum vulgare L. on two cabbage pests. Environ. Entomol., 21, 837-844.

12. Iqbal M.F., Kahloon M.H., Nawaz M.R., Javaid M.I. 2011. Effectiveness of some botanical extracts on wheat aphids. JAPS, 21(1), 114-115.

13. Karaborklu S., Ayvaz A., Yilmaz S., Akbulut M. 2011. Chemical Composition and Fumigant Toxicity of Some Essential Oils Against Ephestia kuehniella. J. Econ. Entomol., 104, 1212-1219. 
14. Konieczny M., Ślęzak E. 2019. The inflence of the environment on the content of macro- and microelements in the Tanacetum vulgare. J. Ecol. Eng., 20(4), 1-7.

15. Landolt P.J., Hofstetter R.W., Biddick L.L. 1999. Plant essential oils as arrestants and repellents for neonate larvae of the codling moth (Lepidoptera : Tortricidae). Environ. Entomol., 28, 954-960.

16. Palsson K., Jaenson T.G.T., Baeckstrom P., BorgKarlson A.-K. 2008. Tick repellent substances in the essential oil of Tanacetum vulgare. J. Med. Entomol. 45, 88-93.

17. Reddy G.V.P, Shrestha G., Miller D.A., Oehlschlager A. C. 2018. Pheromone-Trap Monitoring System for Pea Leaf Weevil, Sitona lineatus: Effects of Trap Type, Lure Type and Trap Placement within Fields. Insects 9(3), 75.

18. Rusin M., Gospodarek J., Biniaś B. 2016 a. Effect of aqueous extracts from tarragon (Artemisia dracunculus L.) on feeding of selected crop pests. J. Res. Appl. Agric. Eng., 61(4), 143-146.

19. Rusin M., Gospodarek J., Biniaś B. 2016 b. Effect of water extracts from Artemisia absinthium L. on feeding of selected pests and their response to the odor of this plant. JCEA, 17 (1), 188-206.

20. Rusin M,. Gospodarek J. 2018. The Effcts of Water Extracts from Lemon Balm on Pea Leaf Weevil and Black Bean Aphid Behaviour. J. Ecol. Eng., 19(6), 139-145.

21. Shah M.A., Jandrajupalli S., Venkateshwarlu V., Malik K., Bhatnagar A., Sharma S., 2018. Population Ecology of Aphid Pests Infesting Potato. In: Gaba, S., Smith, B., Lichtfouse, E. (Eds.), Sustainable Agriculture Reviews 28: Ecology for Agriculture. Springer International Publishing Ag., Cham., 153-181.

22. Suomi D., Brown J. J., Akre R. D. 1986. Responses to plant extracts of neonatal codling moth larvae, Cydia pomonella (L.), (Lepidoptera: Tortricidae: Olethreutinae). J. Entomol. Soc. B.C., 83:12-18.

23. Vankosky M., Cárcamo H., Dosdall L. 2011. Identification of potential natural enemies of the pea leaf weevil, Sitona lineatus L. in western Canada. J. Appl. Entomol., 135, 293-301. 